\title{
Analisis Pengaruh Budaya Organisasi Terhadap Kinerja Anggota Kepolisian Resort Malang
}

\author{
Achmad Sani \\ Dosen Tetap Fakultas Ekonomi UIN Mlang
}

\begin{abstract}
The Study aims at : 1) describing the organization culture and performance, 2) finding out the simultaneuos influence of organization culture (variables of innovation, reward, cooperartion or team work, result or outcome orientation and service orientation) on the performance.

This is an explanatory research involving the employees of Polresta Malang as the analysis unit. The studi used proportional random sampling method and to collect data from 81 respondent a questionnaire was used. The analysis technique used were multiple, partial regression, and determination.

The result of study showed that :1) simultaneously the organizational culture significantly influenced the performance, 2) partially the organization culture had also positive influence on the performance, 3) reward had the most significant influence on the performance.

Based on the finding, therefore it is suggested that the organization pay more attention to reward, either material reward or non material reward, since reward is basically a dominant variable in influencing performance.
\end{abstract}

Key word : organization culture, influence, and performance

Ulul Albab, Vol. 5 No. 2, 2004 


\section{A. Latar Belakang Masalah}

Dampak reformasi yang sedang berlangsung saat ini adalah adanya tuntutan perubahan yang mendasar terhadap aspek ekonomi, politik, pertahanan dan keamanan serta hukum. Hal ini akan berdampak pula pada tekanan dan pengawasan masyarakat secara langsung pada penyelenggaraan aparatur negara terhadap pelayanan yang selama ini telah diberikan.

Seperti yang kita cermati bersama bahwa perubahan lingkungan yang terjadi selama ini menunjukkan terjadinya suatu perubahan yang tidak dapat lagi dibatasi oleh ruang dan kurun waktu tertentu, semuanya terjadi begitu cepat, dan bahkan sifat perubahannya hampir tidak pasti dan tidak dapat diperhitungkan sebelumnya. Perubahan yang paling nyata dapat terlihat pada lingkungan masyarakat dimana mereka berupaya untuk menuju terwujudnya masyarakat yang madani yang diyakini sebagai nuansa baru bagi masyarakat, bangsa dan negara Indonesia dimasa yang akan datang. Ciri dari masyarakat tersebut diantaranya adalah menjunjung tinggi akan supremasi hukum, moral dan etika, demokratisasi, hak asasi manusia, transparansi dan keadilan (Roesmanhadi, 1999:1).

Kepolisian Republik Indonesia (POLRI) sebagai aparatur penegakan hukum, tidak terlepas dari pengaruh perubahan kondisi politik yang terjadi di Indonesia. Keluarnya Tap MPR Nomor X/MPR/1998 tentang pokok-pokok Reformasi Pembangunan dalam rangka menyelamatkan normalisasi kehidupan nasional sebagai haluan negara, selanjutnya ditindaklanjuti dengan Instruksi Presiden Nomor 2 Tahun 1999 tentang langkah-langkah kebijakan dalam rangka pemisahan Kepolisian Negara Republik Indonesia dari ABRI (Angkatan Bersenjata Republik Indonesia) (Roesmanhadi, 1999:2).

Pada tanggal 1 April 1999 sebagai era baru bagi Kepolisian Republik Indonesia (POLRI), di mana telah dimulai proses kemandirian POLRI dengan melakukan perubahan struktural, sehingga menempatkan sistem dan penyelenggaraan pembinaan kekuatan dan operasional Polri pada Departeman Pertahanan dan Keamanan (DepHankam). Momentum tersebut kemudian tidak disia-siakan oleh Polri untuk sesegera mungkin merumuskan kembali kedudukan, tugas, dan peran Polri yang lebih sesuai dengan aspirasi masyarakat yang mengarah pada kehidupan negara yang lebih demokratis dalam tatanan masyarakat madani.

Ulul Albab, Vol. 5 No. 2, 2004 
Menurut Roesmanhadi (1999:2) dalam upaya untuk melakukan pembenahan organisasi di lingkungan Polri terdapat 3 (tiga ) aspek yang perlu mendapatkan perhatian yang serius, di mana ketiga aspek tersebut merupakan satu kesatuan yang utuh yang tidak dapat dipisahkan, yaitu:

1. Aspek Struktural, ditinjau dari aspek struktural bahwa pada masa transisi seperti sekarang ini, Polri untuk sementara waktu masih berada di bawah Dephankam, sehingga masih terasa bahwa proses kemandirian Polri masih memerlukan waktu tertentu dalam menuju statusnya sebagai suatu lembaga pemerintah non departeman yang langsung di bawah Presiden. Sebenarnya dengan status Polri yang mandiri diharapkan Polri akan memiliki peluang yang lebih besar untuk meningkatkan kinerja dalam rangka memberikan pelayanan kepada masyarakat.

2. Aspek Instrumental, perubahan dalam aspek ini meliputi, visi, misi, tujuan, doktrin, kewenangan, kompetensi, kemampuan fungsi dan ilmu pengetahuan yang kesemuanya akan dijadikan sebagai pedoman untuk membentuk budaya pelayanan Polri sebagai abdi dan pelayan masyarakat serta menjaga ketertiban masyarakat.

3. Aspek Kultural (budaya), merupakan aspek yang sangat vital dari perubahan pada kedua aspek yang lainnya. Di mana pada akhimya perubahan atau pembaharuan Polri harus terwujud dalam bentuk dan kualitas pelayanan yang aktual Polri terhadap masyarakat. Sehingga baik secara langsung maupun tidak langsung budaya kepolisian akan tercermin pada sikap dan perilaku setiap insan Polri dalam penyelenggaraan tugas penegakan hukum, perlindungan, bimbingan dan pengayoman masyarakat.

Berdasarkan pengamatan peneliti, bahwa permasalahan yang ada di Polresta Malang dapat terlihat dalam melaksanakan tugasnya selama ini, masih terdapat ketidakpuasan masyarakat terhadap pelayanan yang telah diberikan oleh anggota kepolisian. Permasalahan-permasalahan tersebut sering terjadi dalam praktek keseharian di lapangan, hal ini akan membuat masyarakat dengan cepat merespon negatif. Dengan demikian Polri harus mawas diri, tidak perlu melempar kesalahan, hanya karena alasan kendala tidak berimbangnya 
rasio personel Polri dengan jumlah masyarakat atau dengan alasan kesejahteran Polri yang dipertimbangkan belum cukup untuk dikatakan sejahtera.

Kondisi obyektif seperti ini merupakan sebagian dari permasalahan yang dialami Polri saat ini, termasuk juga Kepolisian Resort Malang (Polresta Malang), sehingga diperlukan usaha yang keras untuk memperbaiki permasalahan agar mampu meningkatkan kinerja secara menyeluruh.

Penelitian ini berusaha untuk mengkaji lebih mendalam tentang pengaruh Organization Culture dan Pengaruhnya terhadap Kinerja Anggota Kepolisian Resort Malang. Perumusan Masalah dalam penelitian ini adalah (1) apakah budaya organisasi yang terdiri dari inovasi, imbalan, kerja sama, dan pelayanan berpengaruh signifikan (simultan dan parsial) terhadap kinerja anggota kepolisian di Polresta Malang (2) diantara unsur-unsur budaya organisasi, mana yang berpengaruh dominan terhadap kinerja anggota kepolisian di Polresta Malang?

\section{B. Kerangka Konseptual dan Hipotesis Penelitian \\ 1. Model Konseptual Penelitian}

Model konseptual Penelitian

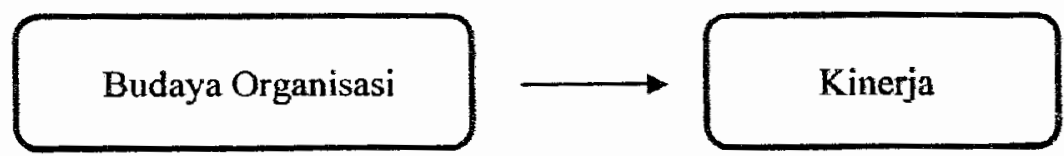

2. Model Hipotesis Penelitian

Model Hipotesis Budaya Organisasi dan Kinerja

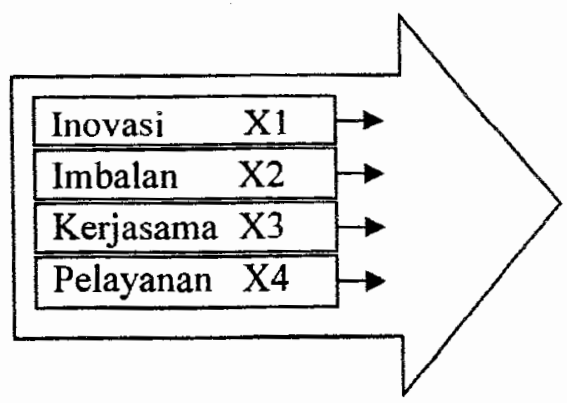

Kinerja Anggota Kepolisian $\mathrm{Y}$

Ulul Albab, Vol. 5 No. 2, 2004 


\section{Keterangan :}

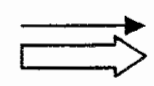

Pengaruh secara parsial variabel Xi terhadap variabel $Y$

Pengaruh secara simultan variabel $\mathrm{Xi}$ terhadap variabel $\mathrm{Y}$

Berdasarkan latar belakang masalah, perumusan masalah dan tinjauan pustaka yang telah disajikan serta kerangka pikiran, maka hipotesisnya dapat dirumuskan sebagai berikut:

1. Bahwa unsur-unsur budaya organisasi yang terdiri dari inovasi, imbalan, kerjasama, dan pelayanan berpengaruh signifikan (simultan dan parsial) terhadap kinerja anggota kepolisian.

2. Bahwa variabel imbalan merupakan variabel yang berpengaruh dominan terhadap kinerja anggota kepolisian.

\section{METODE PENELITIAN}

\section{Jenis Penelitian}

Jenis penelitian ini adalah penelitian eksplanatori. Penelitian eksplanatoris (explanatory research) adalah untuk menguji hipotesa antar variabel yang dihipotesiskan. Pada jenis penelitian ini, jelas ada hipotesis yang akan diuji kebenarannya. Hipotesis itu sendiri mengambarkan hubungan antara dua variabel; untuk mengetahui apakah suatu variabel berasosiasi ataukah tidak dengan variabel lainnya; atau apakah suatu variabel disebabkan ataukah tidak oleh variabel lainnya (Faisal, 1992:21).

\section{Ruang Lingkup Penelitian}

Penelitian ini mengambil ruang lingkup tentang pengelolaan sumber daya manusia dengan fokus untuk menganalisa pengaruh unsur-unsur budaya organisasi yang terdiri dari inovasi, imbalan, kerjasama, dan pelayanan serta pengaruhnya terhadap kinerja anggota kepolisian di Polresta Malang.

Unit analisis dalam penelitian ini adalah individu, yaitu anggota kepolisian di Polresta Malang. Pertimbangan dipilihnya semua anggota karena pada dasarnya semua anggota sudah memahami dan terikat dengan budaya yang ada.

Ulul Albab, Vol. 5 No. 2, 2004 


\section{Definisi Operasional (Variabel)}

Variabel, Indikator, Butir Pertanyaan

\begin{tabular}{|c|c|c|}
\hline Variabel & Indikator & Butir Pertanyaan \\
\hline Inovasi $(\mathrm{X} 1)$ & $\begin{array}{l}\text { 1. Penciptaan } \\
\text { ide } \\
\\
\begin{array}{c}\text { 2. Fleksibilatas } \\
\text { kerja }\end{array}\end{array}$ & $\begin{array}{l}\text { 1. Organisasi mendorong anda untuk } \\
\text { menciptakan ide atau gagasan baru dalam } \\
\text { melaksanakan tugas (X1.1) } \\
\text { 2. Anggota kepolisian telah berusaha } \\
\text { menciptakan ide atau gagasan baru dalam } \\
\text { melaksanakan tugas (X1.2) } \\
\text { 3. Organisasi memberikan peluang kepada anda } \\
\text { untuk mengimplementasikan ide tersebut } \\
\text { (X1.3) } \\
\text { 1. Organisasi memberikan keleluasaan untuk } \\
\text { berteindak lebih fleksibel dalam bekerja } \\
\text { (X1.4) meleluasaan } \\
\text { 2. Organisasi memberikan } \\
\text { berimprovisasi untuk mencapai tujuan } \\
\text { organisasai (X1.5) } \\
\text { 3. Anggota kepolisian sudah melaksanakan } \\
\text { keleluasaan dalam berimprovisasi untuk } \\
\text { mencapai tujuan organisasi (X1.6) }\end{array}$ \\
\hline $\begin{array}{l}\text { Imbal } \\
(\mathrm{X} 2)\end{array}$ & $\begin{array}{l}\text { 1. Imbalan } \\
\text { material }\end{array}$ & $\begin{array}{l}\text { 1. Besarnya gaji yang diberikan sesuai dengan } \\
\text { yang diharapkan (X2.1) } \\
\text { 2. Organisasi memberikan gaji sesuai dengan } \\
\text { pengorbanan yang telah anda berikan kepada } \\
\text { organisasi (X2.2) } \\
\text { 3. Organisasi memberikan tunjangan } \\
\text { kesehatan, perumahan dll kepada setiap } \\
\text { anggota sesuai dengan yang diharapkan } \\
\text { (X2.3) } \\
\text { 4. Organisasi memberikan insentif sesuai } \\
\text { dengan yang diharapkan (X2.4) } \\
\text { 1. Apabila anggota berprestasi maka organisasi } \\
\text { akan mempromosikan pada jabatan yang } \\
\text { lebih baik (X2.5) } \\
\text { 2. Organisasi memberikan penghargaan dan } \\
\text { pengakuan hasil kerja bila berhasil } \\
\text { meningkatkan perbaikan dan melaksanakan } \\
\text { pekerjaan dengan benar (X2.6) }\end{array}$ \\
\hline
\end{tabular}




\begin{tabular}{|c|c|c|}
\hline & & $\begin{array}{l}\text { 3. Perusahaan memberikan kesempatan kepada } \\
\text { anda untuk mengembangkan diri (X2.7) } \\
\text { 4. Salah satu pertimbangan promosi adalah } \\
\text { pengakuan hasil kerja berdasarkan kinerja } \\
\text { (X2.8) }\end{array}$ \\
\hline $\begin{array}{l}\text { Kerjasama } \\
\text { (X3) }\end{array}$ & $\begin{array}{l}\text { 1. Membentuk } \\
\text { kerja tim } \\
\text { 2. Hubungan } \\
\text { kerja } \\
\text { individu } \\
\text { dan } \\
\text { kelompok }\end{array}$ & $\begin{array}{l}\text { 1. Saya akan menerima apabila organisasi } \\
\text { membentuk tim kerja untuk melaksanakan } \\
\text { tugas (X3.1) } \\
\text { 2. Organisasi menekankan bahwa keberhasilan } \\
\text { akan tercapai bila adanya kerjasama tim } \\
\text { yang baik /kuat dengan rekan sekerja (X3.2) } \\
\text { 1. Organisasi mendorong agar diantara sesama } \\
\text { rekan sekerja ada rasa saling percaya dan } \\
\text { yakin dalam hubungan kerja (X3.3) } \\
\text { 2. Saya akan menerima bantuan kerjasama } \\
\text { atas segala aktivitas tugas untuk kelancaran } \\
\text { pekerjaan yang dilakukan secara kolektif } \\
\text { (X3.4) }\end{array}$ \\
\hline $\begin{array}{l}\text { Pelayanan } \\
\text { X4) }\end{array}$ & $\begin{array}{l}\text { 2. Perhatian } \\
\text { kepada } \\
\text { masyarakat }\end{array}$ & $\begin{array}{l}\text { 1. Organisasi mengharuskan agar memberikan } \\
\text { pelayanan sesuai dengan waktu yang telah } \\
\text { dijanjikan (X4.1) } \\
\text { 2. Organisasi mengharuskan anda bahwa tugas } \\
\text { utama anda adalah memberikan pelayanan } \\
\text { yang terbaik kepada masyarakat (X4.2) } \\
\text { 1. Organisasi mengharuskan anda sanggup } \\
\text { untuk menenangkan masyarakat yang } \\
\text { mempunyai masalah dengan kepolisian } \\
\text { (X4.3) } \\
\text { 2. Organisasi mengharuskan anda sanggup } \\
\text { untuk menjamin kepuasan masyarakat } \\
\text { (X4.4) }\end{array}$ \\
\hline Kinerja (Y) & 1. Kuantitas & $\begin{array}{l}\text { 1. Penyelesaian jumlah pekerjaan sesuai } \\
\text { dengan standar yang telah ditetapkan (Y.I) } \\
\text { 2. Jumlah pekerjaan yang dapat diselesaikan } \\
\text { melampaui jumlah standar yang ditetapkan } \\
\text { (Y.2) } \\
\text { 3. Jumlah pekerjaan yang dapat diselesaikan } \\
\text { melampaui jumlah yang dihasilkan rekan } \\
\text { sekerja (Y.3) } \\
\text { 1. Penyelesaian pekerjaan sesuai dengan } \\
\text { standar mutu yang ditetapkan (Y.4) } \\
\text { 2. Pekerjaan dapat diselesaikan dengan penuh } \\
\text { ketelitian dan kecermatan (Y.5) }\end{array}$ \\
\hline
\end{tabular}

Ulul Albab, Vol. 5 No. 2, 2004 


\begin{tabular}{|l|l|l|}
\hline & $\begin{array}{l}\text { 3. Pekerjaan dapat diselesaikan dengan rapi } \\
\text { (Y.6) } \\
\text { 4. Pekerjaan dapat diselesaikan secara tuntas } \\
\text { (Y.7) } \\
\text { 5. Setap hasil kerja dapat diterima oleh } \\
\text { organisasi sesuai dengan kualifikasi yang } \\
\text { ditetapkan (Y.8) } \\
\text { 1. Pekerjaan dapat diselesaikan sesuai dengan } \\
\text { target waktu yang ditetapkan (Y.9) } \\
\text { 2. Pekerjaan dapat diselesaikan melampaui } \\
\text { target waktu yang ditetapkan (Y.10) }\end{array}$ \\
\hline
\end{tabular}

\section{Uji Validitas Dan Reliabilitas \\ Validitas.}

Suatu instrumen dikatakan valid apabila mampu mengukur apa yang diinginkan serta dapat mengungkap data dari variabel yang diteliti dengan tepat.. Validitas alat ukur menunjukkan sejauh mana data yang terkumpul tidak menyimpang dari gambaran variabel yang dimaksud. Instrumen dikatakan valid apabila koefisien korelasinya $\geq 0,3$ dengan $\alpha=0,05$, jadi karena semua item lebih besar dari 0,3, maka instrumen tersebut dapat Dikatakan valid. (Sugiyono, 1999: 115).

\section{Reliabilitas}

Suatu instrumen dapat dikatakan reliabel, jika dapat dipakai untuk mengukur suatu gejala pada waktu berlainan senantiasa menunjukan hasil yang sama atau secara konsisten memberi hasil ukuran yang sama. Reliabilitas adalah suatu indeks yang menunjukkan sejauh mana instrumen dapat dipercaya atau dapat diandalkan. $\mathrm{Uji}_{\mathrm{ji}}$ reliabilitas ini menggunakan rumus Alpha Cronbach . Instrumen dapat dikatakan reliabel apabila nilai koefisien alphanya $\geq 0,6$ (Arikunto, $1991: 138$ ). Sehinga dalam penelitian ini koefisien alphanya lebih besar dari 0,6 , maka semua itemnya reliabel. 


\section{Populasi dan Teknik Pengambilan Sampel}

\section{a. Populasi}

Pada penelitian ini populasinya adalah seluruh anggota kepolisian Polresta Malang. Selain itu peneliti tidak memandang kepangkatan, tidak membedakan atasan maupun bawahan

\section{b. Sampel}

Agar sampel yang diambil dapat dikatakan representatif maka dalam penelitian ini ditentukan jumlah sampel yang dihitung dengan menggunakan rumus Slovin dalam Umar (1999:108) sebagai berikut:

$$
\mathrm{n}=\frac{\mathrm{N}}{1+\mathrm{N} \mathrm{e}^{2}}
$$

Keterangan:

$\mathrm{N}=$ ukuran populasi, yaitu 408 anggota kepolisian.

$\mathrm{n}=$ ukuran sampel

$\mathrm{e}=$ prosentase kelonggaran ketidaktelitian (presisi) karena kesalahan pengambilan sampel yang masih dapat ditolerir atau diinginkan.

Dengan ukuran populasi 408 orang dan tingkat kelonggaran ketidaktelitian sebesar $10 \%$, maka ukuran sampel dalam penelitian ini adalah: $1+(408)(0,1)^{2}$

$=81$ orang.

\section{Teknik Pengambilan Sampel}

Populasi dalam penelitian ini mempunyai anggota atau unsur yang tidak homogen, yang dibagi dalam kesatuan yang ada, dimana jumlah anggota untuk masing-masing kesatuan berbeda. Dengan demikian teknik pengambilan sampel yang digunakan dalam penelitian ini adalah metode proportional random sampling, yaitu teknik pengambilan sampel secara acak dengan jumlah yang proportional untuk masing-masing sub populasi (Sugiyono, $1999: 75$ ). Dalam penelitian ini sampel diambil tidak memandang pangkat, tidak membedakan atasan dan bawahan.

Ulul Albab, Vol. 5 No. 2, 2004 


\section{Teknik Pengumpulan Data}

Dalam penelitian ini, digunakan teknik pengumpulan data sebagai berikut:

1. Kuesioner, merupakan suatu angket yang disusun secara terstruktur guna menjaring data, sehingga diperoleh data akurat berupa tanggapan langsung responden..

2. Wawancara, merupakan metode pengumpulan data dengan cara bertanya langsung (berkomunikasi langsung) dengan responden (Soeratno dan Arsyad, 1999:92),

3. Dokumentasi, dalam hal ini data diperoleh dengan cara mempelajari, mencatat, atau membuat salinan dari dokumen atau arsip-arsip yang berhubungan dengan permasalahan penelitian termasuk laporanlaporan, karya tulis dan sebagainya yang dapat menunjang penelitian.

\section{Teknik Analisis Data}

Pada penelitian ini analisis data dilakukan dengan tahapan sebagai berikut:

\subsection{Analisis Deskriptif}

Analisis ini dipakai untuk mendeskripsikan persepsi responden yang diteliti dalam bentuk distribusi frekuensi persentase menurut variabel, indikator dan item..

\subsection{Analisis Regresi Linier Berganda}

Untuk melihat pengaruh dua variabel bebas atau lebih terhadap variabel terikat secara bersama-sama yang ditunjukkan oleh koefisien regresi (bi). Rumus persamaan regresinya adalah:

$$
Y=\beta_{0}+\beta_{1} X_{1}+\beta_{2} X_{2}+\beta_{3} X_{3}+\beta_{4} X_{4}+\epsilon
$$

Keterangan :

$\mathrm{Y} \quad=$ kinerja anggota kepolisian

$\beta_{0} \quad=$ bilangan konstanta

$\beta_{1} \ldots . \beta \mathrm{i}=$ koefisien regresi $\mathrm{Xi}$

$\mathrm{X}_{1} \quad$ = inovasi 


$$
\begin{array}{ll}
\mathrm{X}_{2} & =\text { imbalan } \\
\mathrm{X}_{3} & =\text { kerja sama } \\
\mathrm{X}_{4} & =\text { pelayanan } \\
\epsilon & =\text { variabel pengganggu }
\end{array}
$$

Pengujian hipotesis pertama dilakukan dengan memanfaatkan uji statistik F (uji serentak) z dengan rumus (Sudjana, 1992:385):

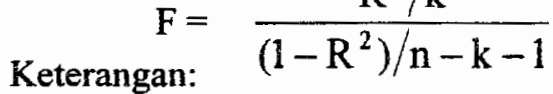

$$
\begin{aligned}
& F=\text { rasio } \\
& R^{2}=\text { hasil perhitungan } R \text { dipangkatkan dua } \\
& k=\text { jumlah variabel bebas } \\
& n=\text { banyaknya sampel }
\end{aligned}
$$

Berdasarkan hipotesis yang telah diajukan di muka, maka untuk pengujian hipotesis (1), diuji sebagai berikut:

$\mathrm{H}_{0}: \beta_{1}=\beta_{2}=\beta_{3}=\beta_{4}=0$, artinya secara bersama-sama tidak ada pengaruh yang signifikan antara variabel $X_{1}, X_{2}, X_{3}, X_{4}$ terhadap variabel $Y$.

$H_{1}: \beta_{1} \neq \beta_{2} \neq \beta_{3} \neq \beta_{4} \neq 0$, artinya secara bersama-sama ada pengaruh yang signifikan antara variabel $X_{1}, X_{2}, X_{3}, X_{4}$ terhadap variabel $Y$.

Kriteria pengambilan keputusan:

Jika probabilitas $\mathrm{F}_{\text {hitung }} \leq_{(\alpha=0,05)}$ berarti persamaan regresi berganda baik digunakan untuk melakukan penaksiran pengaruh variabel bebas terhadap variabel terikat. Bila asumsi klasik tidak ada yang dilanggar dan hasil koefisien regresi berganda signifikan, artinya bahwa signifikansinya lebih kecil dari 0,05 maka hipotesis pertama diterima.

\subsection{Analisis Regresi Parsial}

Untuk mengetahui pengaruh variabel bebas secara parsial terhadap variabel terikat, sementara sejumlah variabel bebas lainnya yang diduga mempunyai pertautan dengan variabel terikat tersebut dianggap konstan 
digunakan uji regresi parsial. Pengujian hipotesis kedua dilakukan dengan memanfaatkan jji statistik $t$ student. Rumus yang digunakan adalah :

$$
\begin{aligned}
& \mathrm{t}=\frac{\mathrm{bi}}{\mathrm{Se}_{\mathrm{f}}} \\
& \text { Keterăfhgan : } \\
& \mathrm{bi} \quad=\text { penduga bagi } \beta \mathrm{i} \\
& \mathrm{Se}_{(\mathrm{bi})}=\text { standard error dari } \beta \mathrm{i}
\end{aligned}
$$

Kriteria pengambilan keputusan adalah :

Jika probabilitas $\mathrm{t}$ hitung $\leq \alpha$ maka $\mathrm{H}_{0}$ ditolak

Jika probabilitas thitung $>\alpha$ maka $\mathrm{H}_{0}$ diterima

Bila $\mathrm{H}_{0}$ ditolak berarti $\mathrm{H}_{1}$ diterima, yang secara langsung menyatakan variabel-variabel bebas yang diuji secara parsial mempunyai pengaruh yang signifikan terhadap variabel terikat, dengan demikian hipotesis kedua dapat diterima.

\subsection{Uji t}

Pengujian hipotesis ketiga yaitu diduga variabel imbalan merupakan variabel yang berpengaruh dominan terhadap kinerja anggota kepolisian Polresta Malang. Pengujian hipotesis ini dilakukan dengan memanfaatkan uji statistik $t$ student. Rumus yang digunakan adalah (Sugiarto, $1992: 26$ ):

$$
\begin{aligned}
& \quad t=\frac{b_{1}}{S e_{(b i)}} \\
& \text { Keterangan : } \\
& \text { bi } \quad=\text { penduga bagi } \beta \mathrm{i} \\
& \mathrm{Se}_{(\mathrm{bi})}=\text { standard error dari } \beta \mathrm{i}
\end{aligned}
$$

Untuk mengetahui variabel mana yang mempunyai pengaruh dominan terhadap kinerja, maka dapat dilihat pada nilai t hitungnya. Suatu variabel dikatakan mempunyai pengaruh dominan apabila nilai thitungnya paling besar diantara variabel lainnya.

\subsection{Koefisien determinasi}

Untuk mencari persentase total variasi dalam variabel terikat $(Y)$ yang dijelaskan oleh variabel bebas $(X)$ secara bersama-sama dan juga untuk mengukur besar sumbangan dari variabel bebas $X$ terhadâp ragam variabel 
terikat $\mathrm{Y}$, dinyatakan dengan koefisien determinasi majemuk yang dilambangkan dengan $R^{2}$ (Sugiarto, $1992: 81$ ), yaitu :

$$
\begin{aligned}
& \mathrm{R}^{2}=\frac{\text { JKRegres } 1}{\text { KK Total Trikoreksi }} \times 100 \% \\
& \text { Koefisien lakn yang dipertimbangkan dalam analisis regresi } \\
& \text { adalah koefisien determinasi yang terkoreksi atau disesuaikan } \\
& \overline{\mathrm{R}^{2}}=\left[1-\frac{\mathrm{n}-1}{\mathrm{n}-\mathrm{k}-\mathrm{l}}\left[1-\mathrm{R}^{2}\right]\right] \times 100 \%
\end{aligned}
$$

Semakin besar $k$ ofeisisien determinasi terkoreksi suatu model regresi, maka model yang didapatkan akan semakin baik.

\section{HASIL PENELITIAN DAN PEMBAHASAN}

\section{HASIL PENELITIAN}

\subsection{Visi dan Misi Polresta Malang}

Visi : Polresta Malang adalah mampu menjadi pelindung, pengayom, dan pelayan masyarakat yang selalu dekat dan bersama-sama dengan masyarakat, serta sebagai aparat penegak hukum yang profesional dan proporsional yang selalu menjunjung tinggi supremasi hukum dan hak asasi manusia, pemelihara kamtibmas, serta mewujudkan keamanan dalam negeri dalam suatu kehidupan nasional yang demokratis dan masyarakat yang sejahtera.

Sebagai pelindung dan pengayom, polri adalah sosok pelayan atau pengabdi yang harus selalu simpatik, selalu memberikan $3 \mathrm{~S}$ (senyum, sapa, salam), harus cepat tanggap dan lugas dalam menerima laporan dan keluhan masyarakat, harus menjadi polisi yang etis, manusiawi, dekat dengan masyarakat. Dengan visi tersebut, Polri harus mengedepankan perannya selaku pelindung, pengayom,dan pelayan masyarakat yang mengutamakan pendekatan preventif dan persuasif. Tindakan represif dan penggunaan kekerasan adalah langkah terakhir apabila harus dilakukan untuk menghentikan dan mencegah meluasnya tindakan anarkhis.

Misi Polri kedepan adalah :

a. Memberikan perlindungan, pengayoman, dan pelayanan kepada masyarakat (meliputi aspek security, surety, safety dan safe) sehingga masyarakat bebas dari gangguan fisik maupun psikis. 
b. Memberikan bimbingan kepada masyarakat melalui upaya preventif yang dapat meningkatkan kesadaran dan kekuatan hukum masyarakat.

c. Menegakkan hukum secara profesional dan proporsional dengan menjunjung tinggi supremasi hukum dan hak asasi manusia menuju kepastian hukum dan rasa keadilan.

d. Memelihara keamanan dan ketertiban masyarakat dengan tetap mempertahankan norma-norma dan nilai yang berlaku dalam bingkai integritas wilayah hukum negara kesatuan Republik Indonesia.

e. Mengelola sumber daya manausia yang profesional dalam mencapai tujuan Polri yaitu terwujudnya keamanan dalam negeri

f. Melanjutkan upaya konsolidasi kedalam (internal Polri) sebagai upaya untuk menyamakan visi dan misi Polri kedepan.

g. Memelihara solidaritas institusi Polri dari berbagai pengaruh eksternal yang sangat merugikan organisasi.

1.2. Gambaran Umum Responden

Tabel 1. Distribusi Usia Responden

\begin{tabular}{|c|c|c|}
\hline Usia & Frekuensi & Persentase \\
\hline 20-29 tahun & 23 & 28,4 \\
$30-39$ tahun & 20 & 24,7 \\
$40-49$ tahun & 32 & 39,5 \\
$50-59$ tahun & 6 & 7,4 \\
\hline Jumlah & 81 & 100 \\
\hline
\end{tabular}

Pada Tabel 1 dapat diketahui bahwa dari 81 jumlah responden yang ditetapkan, terdapat 23 responden $(28,4 \%)$ yang berusia antara $20-29$ tahun, 20 responden $(24,7 \%)$ berusia antara $30-39$ tahun, 32 responden $(39,5 \%)$ berusia antara 40-49 tahun. Responden yang berusia 50-59 tahun sebanyak 6 responden $(7,4 \%)$ 
Tabel 2. Distribusi Jenis Kelamin Responden

\begin{tabular}{|c|c|c|}
\hline Jenis kelamin & Frekuensi & Persentase \\
\hline Pria & 68 & 84,0 \\
Wanita & 13 & 16,0 \\
\hline Jumlah & 81 & 100 \\
\hline
\end{tabular}

Pada Tabel 2 dapat diketahui bahwa dari 81 responden yang ditetapkan, terdapat 68 responden $(84,0 \%)$ berjenis kelamin pria, dan sisanya sebanyak 13 responden $(16,0 \%)$ berjenis kelamin wanita. Ini menunjukkan bahwa komposisi jenis kelamin responden pria cenderung lebih banyak dari wanita, hal ini dikarenakan tuntutan pekerjaan yang penuh resiko di kepolisian, sehingga tenaga kerja pria sangat berperan dalam bidang kerja tersebut.

Tabel 3. Distribusi Pendidikan Responden

\begin{tabular}{|c|c|c|}
\hline Pendidikan & Frekuensi & Persentase \\
\hline SLTA & 67 & 82,7 \\
Diploma & 3 & 3,7 \\
S1 & 10 & 12,4 \\
S2 & 1 & 1,2 \\
\hline Jumlah & 81 & 100 \\
\hline
\end{tabular}

Pada Tabel 3 menunjukkan tingkat pendidikan responden. Dari 81 responden, terdapat 67 responden $(82,7 \%)$ berpendidikan SLTA 3 responden $(3,7 \%)$ berpendidikan diploma, 10 responden $(12,4 \%)$ berpendidikan $\mathrm{S} 1$ dan sisanya sebanyak 1 responden $(1,2 \%)$ berpendidikan S2.

Tabel 4. Distribusi Masa Kerja Responden

\begin{tabular}{|c|c|c|}
\hline Masa Kerja & Frekuensi & Persentase \\
\hline 1-10 tahun & 21 & 25,9 \\
11-20 tahun & 22 & 27,2 \\
$21-30$ tahun & 30 & 37,0 \\
$>30$ tahun & 8 & 9,9 \\
\hline Jumlah & 81 & 100 \\
\hline
\end{tabular}

Ulul Albab, Vol. 5 No. 2, 2004 
Pada Tabel 4 distribusi responden menurut masa kerja menunjukkan 110 tahun sebanyak 21 responden (25,9\%), 11-20 tahun sebanyak 22 responden $(27,2 \%), 21-30$ tahun sebanyak 30 responden $(37,0 \%)$ dan $>30$ tahun sebanyak 8 responden $(9,9 \%)$.

Tabel 5. Distribusi Status Perkawinan Responden

\begin{tabular}{|c|c|c|}
\hline Status Perkawinan & Frekuensi & Persentase \\
\hline Kawin & 63 & 77,8 \\
Belum kawin & 18 & 22,2 \\
\hline Jumlah & 81 & 100 \\
\hline
\end{tabular}

Tabel 5 menunjukkan bahwa dari 81 jumlah responden yang ditetapkan, terdapat 63 responden $(77,8 \%)$ yang sudah kawin, dan sebanyak 18 responden $(22,2 \%)$ yang belum kawin.

\section{HASIL ANALISIS PENELITIAN}

\subsection{Uji Validirtas Dan Reliabilitas}

Tabel 6. Rekapitulasi uji Validitas dan Reliabilitas Instrumen Penelitian

\begin{tabular}{|c|c|c|c|c|c|}
\hline Variabel & Item & $\mathrm{R}$ & Keterangan & Alpha Cronbach & Keterangan \\
\hline \multirow[t]{6}{*}{$\mathrm{X} 1$} & $\mathrm{X} 1.1$ & 0,518 & Valid & \multirow{6}{*}{0,8179} & \multirow{6}{*}{ Reliabel } \\
\hline & $\mathrm{X} 1.2$ & 0,685 & Valid & & \\
\hline & $\mathrm{X} 1.3$ & 0,702 & Valid & & \\
\hline & $\mathrm{X} 1.4$ & 0,827 & Valid & & \\
\hline & $\times 1.5$ & 0,811 & Valid & & \\
\hline & $\times 1.6$ & 0,771 & Valid & & \\
\hline \multirow[t]{8}{*}{$\mathrm{X}_{2}$} & $\mathrm{X} 2.1$ & 0,584 & Valid & \multirow{8}{*}{0,8348} & \multirow{8}{*}{ Reliabel } \\
\hline & $\mathrm{X} 2.2$ & 0,711 & Valid & & \\
\hline & $\mathrm{X} 2.3$ & 0,800 & Valid & & \\
\hline & $\mathrm{X} 2.4$ & 0,852 & Valid & & \\
\hline & $\mathrm{X} 2.5$ & 0,747 & Valid & & \\
\hline & $\mathrm{X} 2.6$ & 0,575 & Valid & & \\
\hline & $\times 2.7$ & 0,655 & Valid & & \\
\hline & $\mathrm{X} 2.8$ & 0,597 & Valid & & \\
\hline
\end{tabular}

Ulul Albab, Vol. 5 No. 2, 2004 


\begin{tabular}{|c|c|c|c|c|c|}
\hline \multirow[t]{4}{*}{$\mathrm{X} 3$} & $\mathrm{X} 3.1$ & 0,651 & Valid & \multirow{4}{*}{0,7245} & \multirow{4}{*}{ Reliabel } \\
\hline & $\mathrm{X} 3.2$ & 0,779 & Valid & & \\
\hline & X3.3 & 0,780 & Valid & & \\
\hline & X3.4 & 0,778 & Valid & & \\
\hline \multirow[t]{4}{*}{$\mathrm{X} 4$} & $\mathrm{X} 4.1$ & 0,777 & Valid & \multirow{4}{*}{0,7146} & \multirow{4}{*}{ Reliabel } \\
\hline & $\mathrm{X} 4.2$ & 0,658 & Valid & & \\
\hline & $\mathrm{X} 4.3$ & 0,691 & Valid & & \\
\hline & $\mathrm{X} 4.4$ & 0,811 & Valid & & \\
\hline \multirow[t]{10}{*}{$\mathrm{Y}$} & $\mathrm{Y} 1$ & 0,683 & Valid & \multirow{10}{*}{0,8751} & \multirow{10}{*}{ Reliabel } \\
\hline & $\mathrm{Y} 2$ & 0,728 & Valid & & \\
\hline & $\mathrm{Y} 3$ & 0,718 & Valid & & \\
\hline & Y4 & 0,689 & Valid & & \\
\hline & Y5 & 0,732 & Valid & & \\
\hline & Y6 & 0,711 & Valid & & \\
\hline & Y7 & 0,775 & Valid & & \\
\hline & Y8 & 0,698 & Valid & & \\
\hline & Y9 & 0,803 & Valid & & \\
\hline & Y10 & 0,462 & Valid & & \\
\hline
\end{tabular}

Sumber : data diolah

\subsection{Analisis Deskriptif}

Analisis diskriptif bertujuan untuk mendiskripsikan variabel-variabel penelitian melalui interpretasi distribusi frekuensi jawaban responden secara keseluruhan, baik dalam jumlah responden (orang), maupun dalam angka persentase terhadap item-item variabel inovasi, imbalan, kerjasama, pelayanan, serta kinerja anggota kepolisian.

a. Variabel Inovasi (X1)

Tabel 7. Distribusi Frekuensi Item variabel Inovasi (X1)

\begin{tabular}{|c|c|c|c|c|c|c|c|c|c|c|c|}
\hline \multicolumn{12}{|c|}{ Jawaban Responden } \\
\hline \multirow[t]{2}{*}{ Item } & \multicolumn{2}{|l|}{1} & \multicolumn{2}{|l|}{2} & \multicolumn{2}{|l|}{3} & \multicolumn{2}{|l|}{4} & \multicolumn{2}{|l|}{5} & \multirow[t]{2}{*}{ Mear } \\
\hline & $F$ & $\%$ & $f$ & $\%$ & $\mathrm{~F}$ & $\%$ & $f$ & $\%$ & $f$ & $\%$ & \\
\hline$\times 1.1$ & 0 & 0,0 & 0 & 0,0 & 3 & 3,7 & 65 & 80,2 & 13 & 16,0 & 4,12 \\
\hline$\times 1.2$ & 0 & 0,0 & 2 & 2,5 & 9 & 11,1 & 50 & 61,7 & 20 & 24,7 & 4,09 \\
\hline$\times 1.3$ & 0 & 0,0 & 3 & 3,7 & 16 & 19,8 & 47 & 58,0 & 15 & 18,5 & 3,91 \\
\hline$\times 1.4$ & 1 & 1,2 & 7 & 8,6 & 18 & 22,2 & 43 & 53,1 & 12 & 14,8 & 3,72 \\
\hline
\end{tabular}

Ulul Albab, Vol. 5 No. 2, 2004 


\begin{tabular}{|l|l|l|l|l|l|l|l|l|l|l|l|}
\hline $\mathrm{X} 1.5$ & 1 & 1,2 & 3 & 3,7 & 24 & 29,6 & 42 & 51,9 & 11 & 13,6 & 3,73 \\
\hline $\mathrm{X} 1.6$ & 1 & 1,2 & 8 & 9,9 & 24 & 29,6 & 35 & 43,2 & 13 & 16,0 & 3,63 \\
\hline
\end{tabular}

Sumber : data diolah

Dari variabel inovasi $(\mathrm{Xl})$ pada item organisasi mendorong untuk menciptakan ide atau gagasan baru (X1.1), dari 81, anggota sebanyak 3 orang $(3,7 \%)$ menjawab netral, 65 orang $(80,2 \%)$ menjawab setuju dan 13 orang $(16,0 \%)$ menjawab sangat setuju. Berdasarkan data tersebut, dapat dikatakan bahwa sebagian besar anggota $(96,2 \%)$ setuju bahwa organisasi memberikan dorongan agar anggota mampu untuk menciptakan ide atau gagasan baru dalam melaksanakan tugas. Nilai mean untuk item ini adalah 4,12, maka dapat diartikan rata-rata anggota kepolisian menyatakan setuju bahwa organisasi telah memberikan dorongan bagi setiap anggota untuk dapat menciptakan ide atau gagasan baru dalam pelaksanaan tugas.

Item anggota kepolisian berusaha menciptakan ide atau gagasan baru dalam pelaksanaan tugas (X1.2), dari 81 anggota, sebanyak 2 orang (2,5\%) menjawab tidak setuju, 9 orang $(11,1 \%)$ menjawab netral, 50 orang $(61,7 \%)$ menjawab setuju dan 20 orang $(24,7 \%)$ menjawab sangat setuju. Berdasarkan data tersebut, dapat dikatakan bahwa sebagian besar anggota $(86,4 \%)$ setuju bahwa anggota kepolisian telah berusaha menciptakan ide atau gagasan baru dalam melaksanakan tugas. Nilai mean untuk item ini adalah 4,09 , maka dapat diartikan rata-rata anggota kepolisian telah berusaha untuk menciptakan ide atau gagasan baru dalam pelaksanaan tugas.

Item organisasi memberikan peluang kepada anggota untuk mengimplementasikan ide (X1.3), dari 81 anggota, sebanyak 3 orang $(3,7 \%)$ menjawab tidak setuju, 16 orang $(19,8 \%)$ menjawab netral, 47 orang $(58 \%)$ menjawab setuju dan 15 orang $(18,5 \%)$ menjawab sangat setuju. Berdasarkan data tersebut, dapat diartikan bahwa sebagian besar anggota $(76,5 \%)$ setuju bahwa organisasi telah memberikan peluang kepada anggota untuk dapat mengimplementasikan ide-ide tersebut. Nilai mean untuk item ini adalah 3,91, maka dapat diartikan rata-rata anggota kepolisian menyatakan setuju bahwa organisasi telah memberikan peluang kepada anggotanya untuk dapat mengimplementasikan ide-ide tersebut. 
Item organisasi memberikan keleluasaan untuk bertindak lebih fleksibel dalam bekerja (X1.4), dari 81 anggota, sebanyak 1 orang $(1,2 \%)$ menjawab sangat tidak setuju, 7 orang $(8,6 \%)$ menjawab tidak setuju, 18 orang $(22,2 \%)$ menjawab netral, 43 orang $(53,1 \%)$ menjawab setuju dan 12 orang $(14,8 \%)$ menjawab sangat setuju. Berdasarkan data tersebut, dapat dikatakan bahwa sebagian besar anggota $(67,9 \%)$ setuju bahwa organisasi telah memberikan keleluasaan untuk bertindak lebih flaksibel dalam bekerja. Nilai mean untuk item ini adalah 3,72, maka dapat diartikan bahwa rata-rata anggota kepolisian setuju bahwa organisasi telah memberikan keleluasaan untuk bertindak lebih fleksibel dalam bekerja.

Item organisasi memberikan keleluasaan berimprovisasi untuk mencapai tujuan organisasi $(\mathrm{X} 1.5)$, dari 81 anggota, sebanyak 1 orang $(1,2 \%)$ menjawab sangat tidak setuju, 3 orang $(3,7 \%)$ menjawab tidak setuju, 24 orang $(29,6 \%)$ menjawab netral, 42 orang $(51,9 \%)$ menjawab setuju dan 11 orang $(13,6 \%)$ menjawab sangat setuju. Berdasarkan data tersebut, dapat diartikan bahwa sebagian besar anggota $(65,5 \%)$ setuju bahwa organisasi telah memberikan keleluasaan untuk berimprovisasi dalam mencapai tujuan organisasi. Nilai mean untuk item ini adalah 3,73, maka dapat diartikan bahwa rata-rata anggota kepolisian setuju bahwa organisasi telah memberikan keleluasaan untuk berimprovisasi dalam bekerja untuk mencapai tujuan organisasi.

Item anggota kepolisian telah melaksanakan keleluasaan dalam berimprovisasi untuk mencapai tujuan organisasi (X1.6), dari 81 anggota, sebanyak 1 orang $(1,2 \%)$ menjawab sangat tidak setuju, 8 orang $(9,9 \%)$ menjawab tidak setuju, 24 orang $(29,6 \%)$ menjawab netral, 35 orang $(43,2 \%)$ menjawab setuju dan 13 orang $(16,0 \%)$ menjawab sangat setuju. Berdasarkan data tersebut, dapat dikatakan bahwa sebagian besar anggota $(59,2 \%)$ setuju bahwa anggota kepolisian telah melaksanakan keleluasaan berimprovisasi dalam melaksankan tugas untuk mencapai tujuan organisasi. Nilai mean untuk item ini adalah 3,72, maka dapat diartikan bahwa rata-rata anggota kepolisian telah melaksanakan keleluasaan untuk berimprovisasi dalam melaksanakan tugas untuk mencapai tujuan organisasi.

Nilai mean untuk variabel inovasi yang diperoleh adalah 3,87, maka dapat diartikan rata-rata anggota kepolisian setuju bahwa organisasi telah 
memberikan keleluasaan kepada anggotanya dalam pelaksanaan tugas agar melakukan inovasi-inovasi baru demi mencapai tujuan organisasi.

Dari hasil ini menunjukkan bahwa Kepolisian Resort Malang, melalui kebijakan pimpinan memberikan akses yang seluas-luasnya kepada para anggota Kepolisian untuk bekerja sesuai dengna bidang yang ditangani. Keleluasaan, penciptaan ide baru, fleksibiitas dalam kerja, dan improvisasi dalam tugas diberikan agar anggota Kepolisian dapat bersikap akomodatif dan komunikasi yang baik dengan masyarakat. Hal ini tyelah disadri bahwa Kepolisian yang sekarang bukanlah alat kekuasaan yang berbaju militaer, melainkan Kepolisian adalat alat keamana masayarakat yang harus mengayomi masyarakat. Sehingga masyarakat merasa aman untuk berinteraksi dengan anggota kepolisian.

Tabel 8. Distribusi Frekuensi Item Variabel Imbalan (X2)

\begin{tabular}{|c|c|c|c|c|c|c|c|c|c|c|c|}
\hline \multicolumn{11}{|c|}{ Jawaban Responden } & \multirow[t]{3}{*}{ Mean } \\
\hline \multirow[t]{2}{*}{ Item } & \multicolumn{2}{|l|}{1} & \multicolumn{2}{|l|}{2} & \multicolumn{2}{|l|}{3} & \multicolumn{2}{|l|}{4} & \multicolumn{2}{|l|}{5} & \\
\hline & $\mathrm{F}$ & $\%$ & $f$ & $\%$ & $f$ & $\%$ & $f$ & $\%$ & F & $\%$ & \\
\hline$\times 2.1$ & 15 & 18,5 & 16 & 19,8 & 24 & 29,6 & 21 & 25,9 & 5 & 6,2 & 2,81 \\
\hline$\times 2.2$ & 3 & 3,7 & 12 & 14,8 & 28 & 34,6 & 34 & 42,0 & 4 & 4,9 & 3,30 \\
\hline$\times 2.3$ & 3 & 3,7 & 14 & 17,3 & 22 & 27,2 & 25 & 30,9 & 17 & 21,0 & 3,48 \\
\hline$\times 2.4$ & 2 & 2,5 & 18 & 22,2 & 25 & 30,9 & 24 & 29,6 & 12 & 14,8 & 3,32 \\
\hline$\times 2.5$ & 0 & 0,0 & 5 & 6,2 & 15 & 18,5 & 39 & 48,1 & 22 & 27,2 & 3,96 \\
\hline$\times 2.6$ & 0 & 0,0 & 0 & 0,0 & 15 & 18,5 & 50 & $61_{8} 7$ & 16 & 19,8 & 4,01 \\
\hline$\times 2.7$ & 0 & 0,0 & 1 & 1,2 & 25 & 30,9 & 33 & $39_{s} 2$ & 12 & 14,8 & 3.94 \\
\hline$\times 2.8$ & 0 & 0,0 & 0 & 0,0 & 18 & 22,2 & 46 & 56,8 & 17 & 21,0 & 3,99 \\
\hline
\end{tabular}

Sumber : data diolah

Item besarnya gaji yang diberikan oleh organisasi sesuai dengan yang diharapkan (X2.1), dari 81 anggota, sebanyak 15 orang (18,5\%) menjawab sangat tidak setuju, 16 orang $(19,8 \%)$ menjawab tidak setuju, 24 orang $(29,6 \%)$ menjawab netral, 21 orang $(25,9 \%)$ menjawab setuju dan 5 orang $(6,2 \%)$ menjawab sangat setuju. Berdasarkan data tersebut, dapat dikatakan bahwa sebagian besar anggota $(38,3 \%)$ tidak setuju bahwa besarnya gaji yang diberikan telah sesuai dengan yang diharapkan. Nilai mean untuk item ini 
adalah 2,81, maka dapat diartikan bahwa organisasi belum memberikan gaji yang sesuai dengan yang mereka harapkan.

Item organisasi memberikan gaji sesuai dengan pengorbanan yang telah anda berikan kepada organisasi (X2.2), dari 81 anggota, sebanyak 3 orang $(3,7 \%)$ menjawab sangat tidak setuju, 12 orang $(14,8 \%)$ menjawab tidak setuju, 28 orang $(34,6 \%)$ menjawab netral, 34 orang $(42,0 \%)$ menjawab setuju dan 4 orang $(4,9 \%)$ menjawab sangat setuju. Berdasarkan data tersebut, dapat dikatakan bahwa sebagian besar anggota $(46,9 \%)$ setuju bahwa organisasi telah memberikan gaji sesuai dengan pengorbanan yang telah anda berikan kepada organisasi. Nilai mean untuk item ini adalah 3,30, maka dapat diartikan bahwa organisasi telah memberikan gaji yang sesuai dengan pengorbanan yang telah diberikan kepada organisasi.

Item organisasi memberikan tunjangan kesehatan, perumahan, kepada setiap anggota sesuai dengan yang diharapkan (X2.3), dari 81 anggota, sebanyak 3 orang $(3,7 \%)$ menjawab sangat tidak setuju, 14 orang $(17,3 \%)$ menjawab tidak setuju, 22 orang $(27,2 \%)$ menjawab netral, 25 orang $(30,9 \%)$ menjawab setuju dan 17 orang $(21,0 \%)$ menjawab sangat setuju. Berdasarkan data tersebut, dapat dikatakan bahwa sebagian besar anggota $(51,9 \%)$ setuju bahwa organisasi telah memberikan tunjangan kesehatan, perumahan, kepada setiap anggota sesuai dengan yang diharapkan. Nilai mean untuk item ini adalah 3,48 , maka dapat diartikan bahwa organisasi telah memberikan tunjangan kesehatan, perumahan, kepada setiap anggota sesuai dengan yang diharapkan

Item organisasi memberikan insentif sesuai dengan yang diharapkan (X2.4), dari 81 anggota, sebanyak 2 orang (2,5\%) menjawab sangat tidak setuju, 18 orang $(22,2 \%)$ menjawab tidak setuju, 25 orang $(30,9 \%)$ menjawab netral, 24 orang $(29,6 \%)$ menjawab setuju dan 12 orang $(14,8 \%)$ menjawab sangat setuju. Berdasarkan data tersebut, dapat dikatakan bahwa sebagian besar anggota $(44,4 \%)$ setuju bahwa organisasi telah memberikan insentif sesuai dengan yang mereka harapkan Nilai mean untuk item ini adalah 3,32, maka dapat diartikan bahwa organisasi telah memberikan insentif sesuai dengan yang mereka harapkan

Item organisasi akan mempromosikan pada jabatan yang lebih baik apabila anggota berprestasi (X2.5), dari 81 anggota, sebanyak 5 orang $(6,2 \%)$ 
menjawab tidak setuju, 15 orang $(18,5 \%)$ menjawab netral, 39 orang $(48,1 \%)$ menjawab setuju dan 22 orang $(27,2 \%)$ menjawab sangat setuju. Berdasarkan data tersebut, dapat dikatakan bahwa sebagian besar anggota $(75,3 \%)$ setuju bahwa apabila berprestasi, organisasi akan mempromosikan anda pada jabatan yang lebih baik. Nilai mean untuk item ini adalah 3,96, maka dapat diartikan organisasi mempromosikan anggota ke jabatan yang lebih baik bila berprestasi.

Item organisasi memberikan penghargaan dan pengakuan hasil kerja bila berhasil meningkatkan perbaikan dan melaksanakan pekerjaan dengan benar (X2.6), dari 81 anggota, sebanyak 15 orang (18,5\%) netral, 50 orang $(61,7 \%)$ menjawab setuju dan 16 orang $(19,8 \%)$ menjawab sangat setuju. Berdasarkan data tersebut, dapat dikatakan bahwa sebagian besar anggota $(81,5 \%)$ setuju bahwa organisasi akan memberikan penghargaan dan pengakuan hasil kerja bila anggota berhasil meningkatkan perbaikan dan melaksanakan pekerjaan dengan benar. Nilai mean untuk item ini adalah 4,01, dapat diartikan bahwa organisasi akan memberikan penghargaan dan pengakuan terhadap hasil kerja anggota bila mereka berhasil meningkatkan perbaikan dan melaksanakan pekerjaan dengan benar.

Item organisasi memberikan kesempatan kepada anggota untuk mengembangkan diri $(\mathrm{X} 2.7)$, dari 81 anggota, sebanyak 1 orang $(1,2 \%)$ menjawab tidak setuju, 15 orang $(18,5 \%)$ menjawab netral, 53 orang $(65,4 \%)$ menjawab setuju dan 12 arang $(14,8 \%)$ menjawab sangat setuju. Berdasarkan data tersebut, dapat dikatakan bahwa sebagian besar anggota $(80,2 \%)$ setuju bahwa organisasi memberikan kesempatan kepada semua anggota untuk mengembangkan diri. Nilai mean untuk item ini adalah 3,94, maka dapat diartikan bahwa organisasi memberikan kesempatan kepada para anggota untuk mengembangkan diri.

Item salah satu pertimbangan promosi adalah pengakuan hasil kerja berdasarkan kinerja (X2.8), dari 81 anggota, sebanyak 8 orang $(22,2 \%)$ menjawab netral, 46 orang $(56,8 \%)$ menjawab setuju dan 17 orang $(21,0 \%)$ menjawab sangat setuju. Berdasarkan data tersebut, dapat dikatakan bahwa sebagian besar anggota $(77,8 \%)$ setuju bahwa salah satu pertimbangan promosi adalah pengakuan hasil kerja berdasarkan kinerja. Nilai mean untuk item ini adalah 3,99, maka dapat diartikan bahwa salah satu pertimbangan promosi adalah adanya pengakuan hasil kerja berdasarkan prestasi kerja. 
Nilai mean untuk variabel imbalan yang diperoleh adalah 3,60 , maka dapat diartikan rata-rata anggota kepolisian setuju bahwa organisasi telah memberikan imbalan baik material maupun non material sesuai dengan yang diharapkan.

Tabel 9. Distribusi Frekuensi Item Variabel Kerjasama (X3)

\begin{tabular}{|c|c|c|c|c|c|c|c|c|c|c|c|}
\hline \multicolumn{12}{|c|}{ Jawaban Responden } \\
\hline \multirow[t]{2}{*}{ Item } & \multicolumn{2}{|l|}{1} & \multicolumn{2}{|l|}{2} & \multicolumn{2}{|l|}{3} & \multicolumn{2}{|l|}{4} & \multicolumn{2}{|l|}{5} & \multirow[t]{2}{*}{ Mean } \\
\hline & $F$ & $\%$ & $f$ & $\%$ & $f$ & $\%$ & $F$ & $\%$ & $f$ & $\%$ & \\
\hline$\times 3.1$ & 0 & 0,0 & 2 & 2,5 & 11 & 13,6 & 58 & 71,6 & 10 & 12,3 & 3,94 \\
\hline$\times 3.2$ & 0 & 0,0 & 0 & 0,0 & 8 & 9,9 & 56 & 69,1 & 17 & 21,0 & 4,11 \\
\hline$\times 3.3$ & 0 & 0,0 & 3 & 3,7 & 9 & 11,1 & 48 & 59,3 & 21 & 25,9 & 4,07 \\
\hline$\times 3.4$ & 0 & 0,0 & 8 & 9,9 & 28 & 34,6 & 34 & 42,0 & 11 & 13,6 & 3,60 \\
\hline
\end{tabular}

Sumber : data diolah

Item anggota kepolisian akan menerima apabila organisasi membentuk tim kerja untuk melaksanakan tugas (X3.1), dari 81 anggota, sebanyak 2 orang $(2,5 \%)$ menjawab tidak setuju, 11 orang $(13,8 \%)$ menjawab netral, 58 orang $(71,6 \%)$ menjawab setuju dan 10 orang $(12,3 \%)$ menjawab sangat setuju. Berdasarkan data tersebut, dapat dikatakan bahwa sebagian besar anggota $(83,9 \%)$ setuju bahwa apabila organisasi membentuk tim kerja untuk melaksanakan tugas. Nilai mean untuk item ini adalah 3,94, maka dapat diartikan para anggota akan dapat menerima apabila organisasi membentuk tim kerja untuk melaksanakan tugas.

Item organisasi menekankan bahwa keberhasilan akan tercapai bila adanya kerjasama tim yang lebih baik atau kuat dengan rekan sekerja (X3.2), dari 81 anggota sebanyak 8 orang $(9,9)$ menjawab netral, 56 orang $(69,1 \%)$ menjawab setuju dan 17 orang $(21,0 \%)$ menjawab sangat setuju. Berdasarkan data tersebut, dapat dikatakan bahwa sebagian besar anggota $(90,1 \%)$ setuju apabila organisasi menekankan bahwa keberhasilan akan tercapai bila adanya kerjasama tim yang baik atau kuat dengan rekan sekerja. Nilai mean untuk item 
ini adalah 4,11, maka dapat diartikan bahwa keberhasilan akan tercapai apabila terdapat kerja sama tim yang baik dengan rekan sekerja.

Item organisasi mendorong agar diantara sesama rekan sekerja ada rasa saling percaya dan yakin dalam hubungan kerja (X3.3), dari 81 anggota, sebanyak 3 orang $(3,7 \%)$ menjawab tidak setuju, 9 orang $(11,1 \%)$ menjawab netral, 48 orang $(59,3 \%)$ menjawab setuju dan 21 orang $(25,9 \%)$ menjawab sangat setuju. Berdasarkan data tersebut, dapat dikatakan bahwa sebagian besar anggota $(85,2 \%)$ setuju bahwa organisasi mendorong agar sesama rekan sekerja terdapat saling percaya dan yakin dalam hubungan kerja. Nilai mean untuk item ini adalah 4,07 maka dapat diartikan bahwa organisasi telah mendorong anggota kepolisian agar sesama rekan sekerja ada saling percaya dan yakin dalam hubungan kerja.

Item penerimaan bantuan kerjasama atas aktivitas tugas untuk kelancaran pekerjaan yang dilakukan secara kolektif. (X3.4), dari 81 anggota, sebanyak 8 orang $(9,9 \%)$ menjawab tidak setuju, 28 orang $(34,6 \%)$ menjawab netral, 34 orang $(42,0 \%)$ menjawab setuju dan 11 orang $(13,6 \%)$ menjawab sangat setuju. Berdasarkan data tersebut, dapat dikatakan bahwa sebagian besar anggota $(55,6 \%)$ setuju bahwa para anggota akan menerima bantuan kerjasama atas segala aktivitas tugas untuk kelancaran pekerjaan yang dilakukan secara kolektif. Nilai mean untuk item ini adalah 3,60, maka dapat diartikan bahwa para anggota akan dapat menerima kerjasama atas segala aktivitas tugas untuk kelancaran pekerjaan yang dilakukan secara kolektif.

Nilai mean untuk variabel kerjasama yang diperoleh adalah 3,93, maka dapat diartikan bahwa para anggota dapat menjalin dan menerima bantuan kerjasama atas segala aktivitas tugas demi kelancaran pekerjaan yang dilakukan secara kolektif demi mencapai tujuan organisasi.

\section{Tabel 10. Distribusi Frekuensi Item Variabel Pelayanan (X4)}

\begin{tabular}{|c|c|c|c|c|c|c|c|c|c|c|c|}
\hline \multicolumn{12}{|c|}{ Jawaban responden } \\
\hline \multirow[t]{2}{*}{ Hem } & \multicolumn{2}{|l|}{1} & \multicolumn{2}{|l|}{2} & \multicolumn{2}{|l|}{3} & \multicolumn{2}{|l|}{4} & \multicolumn{2}{|l|}{5} & \multirow[t]{2}{*}{ Mean } \\
\hline & $F$ & $\%$ & $F$ & $\%$ & $f$ & $\%$ & $f$ & $\%$ & $f$ & $\%$ & \\
\hline$X 4.1$ & 1 & 1,2 & 7 & 8,6 & 11 & 13,6 & 53 & 65,4 & 9 & 11,1 & 3,77 \\
\hline$\times 4.2$ & 0 & 0,0 & 1 & 1,2 & 5 & 6,2 & 47 & 58,0 & 28 & 34,6 & 4,26 \\
\hline
\end{tabular}

Ulul Albab, Vol. 5 No. 2, 2004 


\begin{tabular}{|l|l|l|l|l|l|l|l|l|l|l|l|}
\hline $\mathrm{X} 4.3$ & 0 & 0,0 & 2 & 2,5 & 12 & 14,8 & 51 & 63,0 & 16 & 19,8 & 4,00 \\
\hline $\mathrm{X} 4.4$ & 0 & 0,0 & 4 & 4,9 & 11 & 13,6 & 56 & 69,1 & 10 & 12,3 & 3,89 \\
\hline
\end{tabular}

Sumber : lampiran 4

Item organisasi menekankan agar anggota memberikan pelayanan sesuai dengan waktu yang telah dijanjikan (X4.1), dari 81 anggota, sebanyak 1 orang $(1,2 \%)$ menjawab sangat tidak setuju, 7 orang $(8,6 \%)$ menjawab tidak setuju, 11 orang $(13,6 \%)$ menjawab netral, 53 orang $(65,4 \%)$ menjawab setuju dan 9 orang $(11,1 \%)$ menjawab sangat setuju. Berdasarkan data tersebut, dapat dikatakan bahwa sebagian besar anggota $(76,5 \%)$ setuju bahwa organisasi menekankan kepada para anggotanya untuk memberikan pelayanan sesuai dengan waktu yang telah dijanjikan. Nilai mean untuk item ini adalah 3,77, maka dapat diartikan bahwa organisasi menekankan anggotanya agar memberikan pelayanan sesuai dengan waktu yang telah dijanjikan.

Item organisasi menekankan kepada anda bahwa tugas utama anda adalah memberikan pelayanan yang terbaik kepada masyarakat (X4.2), dari 81 anggota, sebanyak 1 orang $(1,2 \%)$ menjawab tidak setuju, 5 orang $(6,2 \%)$ menjawab netral, 47 orang $(58,0 \%)$ menjawab setuju dan 28 orang $(34,6 \%)$ menjawab sangat setuju. Berdasarkan data tersebut, dapat dikatakan bahwa sebagian besar anggota $(92,6 \%)$ setuju bahwa organisasi menekankan kepada anda tugas utama anda adalah memberikan pelayanan yang terbaik kepada masyarakat. Nilai mean untuk item ini adalah 4,26, maka dapat diartikan bahwa organisasi menekankan agar semua anggota kepolisian dapat memberikan pelayanan yang terbaik kepada masyarakat.

Item organisasi menekankan anggota agar sanggup untuk menenangkan masyarakat yang mempunyi masalah dengan kepolisian (X4.3), dari 81 anggota, sebanyak 2 orang $(2,5 \%)$ menjawab tidak setuju, 12 orang $(14,8 \%)$ menjawab netral, 51 orang $(63,0 \%)$ menjawab setuju dan 16 orang $(19,8 \%)$ menjawab sangat setuju. Berdasarkan data tersebut, dapat dikatakan bahwa sebagian besar anggota $(82,8 \%)$ setuju bahwa organisasi selalu menekankan anggota agar sanggup menenangkan masyarakat yang mempunyai masalah dengan kepolisian. Nilai mean untuk item ini adalah 4,00 maka dapat diartikan 
bahwa organisasi selalu menekankan anggota untuk menenangkan masyarakat yang mempunyai masalah dengan kepolisian.

Item organisasi menekankan anggota supaya sanggup menjamin kepuasan masyarakat $(\mathrm{X} 4.4)$, dari 81 anggota, sebanyak 4 orang $(4,9 \%)$ menjawab tidak setuju, 11 orang $(13,6 \%)$ menjawab netral, 56 orang $(69,1 \%)$ menjawab setuju dan 10 orang $(12,3 \%)$ menjawab sangat setuju. Berdasarkan data tersebut, dapat dikatakan bahwa sebagian besar anggota $(81,4 \%)$ setuju bahwa organisasi selalu menekankan kepada setiap anggota agar sanggup menjamin kepuasan masyarakat. Nilai mean untuk item ini adalah 3,98, dapat diartikan bahwa organisasi menekankan setiap anggota sanggup menjamin kepuasan masyarakat.

Nilai mean untuk variabel pelayanan yang diperoleh adalah 3,98 , maka dapat diartikan bahwa organisasi menetapkan kepada setiap anggota kepolisian untuk memberikan pelayanan dengan sebaik-baiknya kepada masyarakat.

Tabel 11. Distribusi frekuensi item variabel kinerja anggota kepolisian (Y)

\begin{tabular}{|c|c|c|c|c|c|c|c|c|c|c|c|}
\hline \multicolumn{12}{|c|}{ Jawaban Responden } \\
\hline \multirow[t]{2}{*}{ Item } & \multicolumn{2}{|l|}{1} & \multicolumn{2}{|l|}{2} & \multicolumn{2}{|l|}{3} & \multicolumn{2}{|l|}{4} & \multicolumn{2}{|l|}{5} & \multirow[t]{2}{*}{ Mean } \\
\hline & $\mathrm{F}$ & $\%$ & $\mathrm{~F}$ & $\%$ & $F$ & $\%$ & $f$ & $\%$ & $f$ & $\%$ & \\
\hline$\gamma_{1}$ & 0 & 0,0 & 1 & 1,2 & 11 & 13,6 & 57 & 70,4 & 12 & 14,8 & 3,99 \\
\hline Y2 & 0 & 0,0 & 7 & 8,6 & 39 & 48,1 & 29 & 35,8 & 6 & 7,4 & 3,42 \\
\hline$Y 3$ & 1 & 1,2 & 6 & 7,4 & 34 & 42,0 & 33 & 40,7 & 7 & 8,6 & 3,48 \\
\hline Y4 & 1 & 1,2 & 3 & 3,7 & 18 & 22,2 & 48 & 59,3 & 11 & 13,6 & 3,80 \\
\hline$Y 5$ & 0 & 0,0 & 1 & 1,2 & 12 & 14,8 & 52 & 64,2 & 16 & 19,8 & 4,02 \\
\hline Y6 & 0 & 0,0 & 0 & 0,0 & 15 & 18,5 & 51 & 63,0 & 15 & 18,5 & 4,00 \\
\hline$Y_{7}$ & 0 & 0,0 & 1 & 1,2 & 18 & 22,2 & 46 & 56,8 & 16 & 19,8 & 3,95 \\
\hline$Y 8$ & 0 & 0,0 & 2 & 2,5 & 16 & 19,8 & 49 & 60,5 & 14 & 17,3 & 3,93 \\
\hline$\gamma 9$ & 0 & 0,0 & 3 & 3,7 & 20 & 24,7 & 45 & 55,6 & 13 & 16,0 & 3,89 \\
\hline$Y_{10}$ & 2 & 2,5 & 15 & 18,5 & 31 & 38,3 & 29 & 35,8 & 4 & 4,9 & 3,22 \\
\hline
\end{tabular}

Sumber : data diolah 
Item penyelesaian jumlah pekerjaan sesuai dengan standar yang ditetapkan (Y1), dari 81 anggota, sebanyak 1 orang $(1,2 \%)$ menjawab tidak setuju, 11 orang $(13,6 \%)$ menjawab netral, 57 orang $(70,4 \%)$ menjawab setujus dan 12 orang $(14,8 \%)$ menjawab sangat setuju. Berdasarkan data tersebut, dapat dikatakan bahwa sebagian besar anggota $(85,2 \%)$ setuju bahwa anggota mampu menyelesaikan pekerjaan sesuai dengan standar yang telah ditetapkan. Nilai mean untuk item ini adalah 3,99, maka dapat diartikan bahwa anggota kepolisian mampu menyelesaikan jumlah pekerjaan sesuai dengan standar yang telah ditetapkan.

Item jumlah pekerjaan yang dapat diselesailkan melampaui jumlah standar yang ditetapkan (Y2), dari 81 anggota, sebanyak 7 orang $(8,6 \%)$ menjawab tidak setuju, 39 orang $(48,1 \%)$ menjawab netral, 29 orang $(35,8 \%)$ menjawab setuju dan 6 orang $(7,4 \%)$ menjawab sangai setuju. Berdasarkan data tersebut, dapat dikatakan bahwa sebagian anggota $(43,2 \%)$ setuju bahwa anggota mampu menyelesaikan pekerjaan melampauj jumiah standar yang ditetapkan. Nilai mean untuk item ini adalah 3,42, maka dapat diartikan bahwa anggota kepolisian telah mampu menyelesaikan jumlah pekerjaan melampau: jumlah standar yang telah ditetapkan.

Item pekerjaan yang telah diselesaikan melampaui jumlah yang dihasilkan oleh rekan sekerja (Y3), dari 81 anggota, sebanyak 1 orang (1,2\%) menjawab sangat tidak setuju, 6 orang $(7,4 \%)$ menjawab tidak setuju, 34 orang (42,0) menjawab netral, 33 orang (40,7\%) menjawab setuju dan 7 orang $(8,6 \%)$ menjawab sangat setuju. Berdasarkan data tersebut, dapat dikatakan bahwa sebagian besar anggota (49,3\%) setuju bahwa anggota mampu menyelesaikan pekerjaan melampaui jumlah yang dihasilkan rekan sekerja. Nilai mean untuk item ini adalah 3,48 , maka dapat diartikan bahwa anggota kepolisian mampu menyelesaikan jumlah pekerjaan melampaui jumlah yang dihasilkan oleh rekan sekerja.

Item penyelesaian pekerjaan sesuai dengan standar mutu yang ditetapkan (Y4), dari 81 anggota, sebanyak 1 orang $(1,2 \%)$ menjawab sangat tidak setuju, 3 orang $(3,7 \%)$ menjawab tidak setuju, 18 orang $(22,2 \%)$ menjawab netral, 49 orang $(59,3 \%)$ menjawab setuju dan 11 orang $(13,6 \%)$ menjawab sangat setuju. Berdasarkan data tersebut, dapat dikatakan bahwa sebagian besar anggota (72,9\%) setuju bahwa anggota mampu menyelesaikan 
pekerjaan sesuai dengan standar mutu yang telah ditetapkan.. Nilai mean untuk item ini adalah 3,80, maka dapat diartikan bahwa anggota kepolisian mampu menyelesaikan pekerjaan sesuai dengan standar mutu yang telah ditetapkan.

Item pekerjaan dapat diselesaikan dengan penuh ketelitian dan kecermatan (Y5), dari 81 anggota, sebanyak 1 orang $(1,2 \%)$ menjawab tidak setuju, 12 orang $(14,8 \%)$ menjawab netral, 52 orang $(64,2 \%)$ menjawab setuju dan 16 orang $(19,8 \%)$ menjawab sangat setuju. Berdasarkan data tersebut, dapat dikatakan bahwa sebagian besar anggota $(84,0 \%)$ setuju bahwa anggota mampu menyelesaikan pekerjaan dengan penuh ketelitian dan kecermatan. Nilai mean untuk item ini adalah 4,02 maka dapat diartikan bahwa anggota kepolisian mampu menyelesaikan pekerjaan dengan penuh ketelitian dan kecermatan

Item pekerjaan dapat diselesaikan dengan rapi (Y6), dari 81 anggota, sebanyak 15 orang $(18,5 \%)$ menjawab netral, 51 orang $(63,0 \%)$ menjawab setuju dan 15 orang $(18,5 \%)$ menjawab sangat setuju. Berdasarkan data tersebut, dapat dikatakan bahwa sebagian besar anggota $(81,5 \%)$ setuju bahwa anggota mampu menyelesaikan pekerjaan dengan rapi. Nilai mean untuk item ini adalah 4,00 maka dapat diartikan bahwa anggota kepolisian mampu menyelesaikan tugas dan pekerjaan yang menjadi tanggung jawabnya dengan rapi.

Item pekerjaan dapat diselesaikan secara tuntas (Y7), dari 81 anggota, sebanyak 1 orang $(1,2 \%)$ menjawab tidak setuju, 18 orang $(22,2 \%)$ menjawab netral, 46 orang $(56,8 \%)$ menjawab setuju dan 16 orang $(19,8 \%)$ menjawab sangat setuju. Berdasarkan data tersebut, dapat dikatakan bahwa sebagian besar anggota $(77,6 \%)$ setuju bahwa anggota mampu menyelesaikan pekerjaan secara tuntas. Nilai mean untuk item ini adalah 3,95, maka dapat diartikan bahwa anggota kepolisian mampu menyelesaikan pekerjaan yang menjadi tanggung jawabnya secara tuntas.

Item setiap hasil kerja dapat diterima oleh organisasi sesuai dengan kualifikasi yang ditetapkan (Y8), dari 81 anggota, sebanyak 2 orang $(5,2 \%)$ menjawab tidak setuju, 16 orang $(19,8 \%)$ menjawab netral, 49 orang $(60,5 \%)$ menjawab setuju dan 14 orang $(17,3 \%)$ menjawab sangat setuju. Berdasarkan data tersebut, dapat dikatakan bahwa sebagian besar anggota $(77,8 \%)$ setuju bahwa setiap hasil kerja anggota dapat diterima oleh organisasi bila sesuai dengan kualifikasi yang telah telah ditetapkan. Nilai mean untuk item ini adalah 
3,93, maka dapat diartikan bahwa hasil kerja anggota kepolisian dapat diterima organisasi apabila sesuai dengan kualifikasi yang telah ditetapkan.

Item pekerjaan dapat diselesaikan sesuai dengan target waktu yang telah ditetapkan (Y9), dari 81 anggota, sebanyak 3 orang (3,7\%) menjawab tidak setuju, 20 orang $(24,7 \%)$ menjawab netral, 45 orang $(55,6 \%)$ menjawab setuju dan 13 orang $(16,0 \%)$ menjawab sangat setuju. Berdasarkan data tersebut, dapat dikatakan bahwa sebagian besar anggota $(71,6 \%)$ setuju bahwa anggota mampu menyelesaikan pekerjaan sesuai dengan target waktu yang telah ditetapkan. Nilai mean untuk item ini adalah 3,89, maka dapat diartikan bahwa anggota kepolisian mampu menyelesaikan pekerjaan sesuai dengan target waktu yang telah ditetapkan.

Item pekerjaan dapat diselesaikan melampaui target waktu yang telah ditetapkan (Y10), dari 81 anggota, sebanyak 2 orang (2,5\%) menjawab sangat tidak setuju, 15 orang $(18,5 \%)$ menjawab tidak setuju, 16 orang $(19,8)$ menjawab netral, 46 orang $(56,8 \%)$ menjawab setuju dan 4 orang $(4,9 \%)$ menjawab sangat setuju. Berdasarkan data tersebut, dapat dikatakan bahwa sebagian besar anggota $(61,7 \%)$ setuju bahwa anggota mampu menyelesaikan pekerjaan melampaui target waktu yang telah ditetapkan. Nilai mean untuk item ini adalah 3,22, maka dapat diartikan bahwa anggota kepolisian mampu menyelesaikan pekerjaan melampaui target waktu yang telah ditetapkan.

Nilai mean untuk variabel kinerja yang diperoleh adalah 3,77, maka dapat diartikan bahwa kinerja setiap anggota kepolisian untuk melaksanakan tugas yang menjadi tanggung jawabnya dapat dilakukan dengan baik.

\subsection{Analisis Regresi Linier Berganda}

Rekapitulasi Analisis Regresi Linier Berganda Pengaruh Variabel Inovasi (X1), Imbalan (X2), Kerjasama (X3), Pelayanan (X4) Terhadap Kinerja Anggota Kepolisian ( $Y$ ). 
Tabel 12 : Regresi Linier Berganda

\begin{tabular}{|c|c|c|c|c|c|}
\hline $\begin{array}{l}\text { VARIABEL } \\
\text { BEBAS }\end{array}$ & $\begin{array}{l}\text { KOEFISIEN } \\
\text { REGRESI ( } \beta \text { ) }\end{array}$ & T HITUNG & $\begin{array}{c}\text { PROBAE } \\
\text { ILITAS } \\
\text { (P) }\end{array}$ & 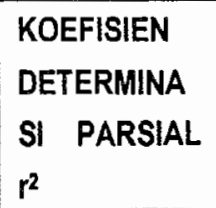 & $\begin{array}{l}\text { KEPUTUSAN } \\
\text { TERHADAP HO }\end{array}$ \\
\hline Konstanta & 0,330 & 0,867 & 0,389 & & \\
\hline $\mathrm{X} 1$ & 0,234 & 2,744 & 0,008 & 0,090 & Ditolak \\
\hline$\times 2$ & 0,214 & 2,758 & 0,007 & 0,091 & Ditolak \\
\hline$\times 3$ & 0,222 & 2,335 & 0,022 & 0,067 & Ditolak \\
\hline$\times 4$ & 0,225 & 2,308 & 0,024 & 0,066 & Ditolak \\
\hline $\begin{array}{l}R^{2} \text { disesuaik } \\
\text { Multiple (R) } \\
\mathrm{N}\end{array}$ & $\begin{aligned} & =0,612 \\
& =0,797 \\
& =81\end{aligned}$ & & & \multicolumn{2}{|c|}{$\begin{array}{l}\text { Probabilitas }=0,000 \\
\alpha=0,05\end{array}$} \\
\hline
\end{tabular}

Sumber : data diolah

Dari Tabel 12 dapat dilihat bahwa nilai $\mathrm{F}$ hitung sebesar 21,974 dengan nilai $p<0,05$, maka $\mathrm{H}_{0}$ ditolak. Hal ini berarti berdasarkan hasil penelitian variabel inovasi, imbalan, kerjasama dan pelayanan secara simultan mempunyai pengaruh yang signifikan terhadap kinerja anggota kepolisian, dengan demikian hipotesis (1) dapat diterima.

Nilai multiple $\mathrm{R}$ sebesar 0,797 , ini mengandung makna bahwa terdapat hubungan yang erat antara variabel inovasi (X1), imbalan (X2), kerjasama (X3) dan pelayanan $(\mathrm{X} 4)$ dengan kinerja anggota kepolisian $(\mathrm{Y})$. Variasi perubahan nilai variabel kinerja anggota kepolisian $(\mathrm{Y})$ yang dapat dijelaskan oleh seluruh variabel bebas; variabel inovasi (X1), imbalan (X2), kerjasama (X3) serta variabel pelayanan $(\mathrm{X} 4)$ yang ditunjukkan oleh angka koefisien determinasi atau $\mathrm{R}^{2}$ disesuaikan yaitu sebesar 0,612 atau sebesar $61,2 \%$ dan selebihnya sebesar 38,8\% dipengaruhi oleh variabel lain.

Berdasarkan hasil pengujian secara parsial terhadap masing-masing variabel bebas dapat diketahui :

1. Hasil analisis regresi untuk variabel inovasi (X1) terhadap variabel kinerja anggota kepolisian $(Y)$ pada Tabel 12 menunjukkan nilai $p(0,008)<\alpha 0,05$. Ini berarti secara parsial ada pengaruh yang signifikan antara variabel 
inovasi terhadap kinerja anggota kepolisian pada taraf signifikansi $95 \%$. Nilai koefisien determinasi parsial $\left(\mathrm{r}^{2}\right)$ yang diperoleh adalah sebesar 0,090 , berarti bahwa variasi perubahan kinerja anggota kepolisian $(Y)$ yang dapat dijelaskan oleh variabel inovasi (X1) sebesar $9,0 \%$. Nilai koefisien regresi $(\beta)$ yang diperoleh adalah positif, yaitu sebesar 0,234.

2. Hasil analisis regresi untuk variabel imbalan (X2) terhadap variabel kinerja anggota kepolisian (Y) pada Tabel 12 menunjukkan nilai $\mathrm{p}(0,007)<\alpha 0,05$. Ini berarti secara parsial ada pengaruh yang signifikan antara variabel imbalan terhadap kinerja anggota kepolisian pada taraf signifikansi $95 \%$. Nilai koefisien determinasi parsial $\left(r^{2}\right)$ yang diperoleh adalah sebesar 0,091 , berarti bahwa variasi perubahan kinerja anggota kepolisian (Y) yang dapat dijelaskan oleh variabel imbalan (X2) sebesar $9,1 \%$. Nilai koefisien regresi $(\beta)$ yang diperoleh adalah positif, yaitu sebesar 0,214 .

3. Hasil analisis regresi untuk variabel kerjasama (X3) terhadap kinerja anggota kepolisian (Y) pada Tabel 12 menunjukkan nilai $\mathrm{p}(0,022)<\alpha 0,05$. Ini berarti secara parsial ada pengaruh yang signifikan antara variabel kerjasama terhadap kinerja anggota kepolisian pada taraf signifikansi 95\%. Nilai koefisien determinasi parsial $\left(\mathrm{r}^{2}\right)$ yang diperoleh adalah sebesar 0,067 , berarti bahwa variasi perubahan kinerja anggota kepolisian $(\mathrm{Y})$ yang dapat dijelaskan oleh variabel kerjasama (X3) sebesar $6,7 \%$. Nilai koefisien regresi $(\beta)$ yang diperoleh adalah positif, yaitu sebesar 0,222 .

4. Hasil analisis regresi untuk variabel pelayanan (X4) terhadap kinerja anggota kepolisian $(Y)$ pada Tabel menunjukkan nilai $p(0,024)<\alpha 0,05$. Ini berarti secara parsial ada pengaruh yang signifikan antara variabel pelayanan terhadap kinerja anggota kepolisian pada taraf signifikansi $95 \%$. Nilai koefisien determinasi parsial $\left(r^{2}\right)$ yang diperoleh adalah sebesar 0,066 , berarti bahwa variasi perubahan kinerja anggota kepolisian (Y) yang dapat dijelaskan oleh variabel kerjasama (X4) sebesar 6,6\%. Nilai koefisien regresi $(\beta)$ yang diperoleh adalah positif, yaitu sebesar 0,225 .

Berdasarkan hasil analisis regresi parsial variabel bebas terhadap variabel terikat pada Tabel 12 menunjukkan nilai $p<0,05$ untuk masingmasing variabel bebas, maka $\mathrm{H}_{0}$ ditolak. $\mathrm{Hal}$ ini berarti variabel inovasi, imbalan, kerjasama dan pelayanan secara parsial mempunyai pengaruh yang 
signifikan terhadap kinerja anggota kepolisian. Berdasarkan hasil analisis regresi linier, maka dapat dihasilkan persamaan regresi sebagai berikut :

$$
\mathrm{Y}=0,330+0,234 \mathrm{X}_{1}+0,214 \mathrm{X}_{2}+0,222 \mathrm{X}_{3}+0,225 \mathrm{X}_{4}
$$

Dapat dijelaskan bahwa konstanta sebesar 0,330 , artinya jika tidak ada $\mathrm{Xi}$, maka kinerja anggota kepolisian sebesar 0,330 . Sedangkan nilai koefisien regresi artinya jika variabel inovasi (X1), imbalan (X2), kerjasama (X3), dan pelayanan (X4) ditingkatkan satu satuan, maka kinerja anggota kepolisian akan meningkat secara berturut-turut sebesar 0,$234 ; 0,214 ; 0,222 ; 0,225$.

\section{KESIMPULAN}

Dari hasil penelitian yang telah dilakukan, maka peneliti dapat menyimpulkan sebagai berikut :

1. Secara simultan dan parsial dapat dikatakan bahwa organization culture kepolisian yang terdiri dari inovasi, imbalan, kerjasama, dan pelayanan berpengaruh terhadap kinerja anggota kepolisian Resort Malang.

2. Budaya Organisasi yang selama ini diterapkan oleh Kepolisian Resort Malang, telah mampu meningkatkan kinerja anggota kepolisian dalam menyelesaikan tugas dan tanggung jawabnya

3. Faktor imbalan merupakan salah satu faktor yang terpenting dalam meningkatkan kinerja anggota kepolisian.

\section{SARAN}

1. Kepolisian Resort Malang hendaknya selalau menjaga budaya organisasai yang selama ini telah berjalan baik dan telah mampu meningkatkan kinerja anggota kepolisian

2. Salah satu faktor yang perlu mendapatkan perhatian dan perbaikan oleh Kepolisian Resort Malang adalah peningkatan imbalan yang diterima anggota, karena faktor imbalan merupakan faktor yang paling berpengaruh terhadap kinerja anggota kepolisian 


\section{DAFTAR PUSTAKA}

Arikunto, Suharsimi. (1991). Prosedur Penelitian, Suatu Pendekatan Praktis. Penerbit Rineka Cipta. Jakarta.

Bernardin, H John \& Russell, Joyce E.A. (1993). Human Resources Management. McGraw Hill. New York.

Byars, Lloyd .L \& Leslie W. Rue. (1995). Human Resources And Personal Management. Richard D Irwin. Inc, Illionis. USA.

Chatman, Jennifer, And Jehn Karen A. (1994). Assesing The Relationship Between Industry Characteristics And Organizational Culture : How Different Can You Be. Academic Of Management Journal. Vol 37.

Dharma, Agus (1991). Manajemen Prestasi Kerja. Edisi Kedua. Penerbit Rajawali. Jakarta.

Djarwanto, P.S \& Subagyo, P. (1993). Statistik Induktif. Edisi IV. BPFE..

Faisal, Sanapiah. (1992). Format-Format Penelitian Sosial. Penerbit Rajawali. Jakarta.

Gujarati, Damodar R. (1999). Ekonometrika Dasar. Cetakan Keenam. alih bahasa Sumarno Zain. Erlangga. Jakarta.

Hadi, Sutrisno. (1990). Analisis Butir Untuk Instrumen. Cetakan Ketiga. Andi Offset. Jakarta.

Harkrisnowo, Harkristuti. (2003). Strategi Penegakan Hukum, Kini Dan Esok, Peran Utama Lembaga Kepolisian. Artikel. Komisi Hukum Nasional.

Hasibuan SP, Malayu. (1990). Manajemen Sumberdaya Manusia : Dasar Dan Kunci Keberhasilan. Cetakan Keenam. CV Haji Masagung. Jakarta.

Jones, B. (1997). How In Doing ? Management Review Jurnal. Volume 86. May. Page 9

Kempton, John. (1995). Human Resources Management and development, Current Issues and Themes. Macmillan Bussiness.

Kotter P Jones and James L Heskett. (1997). Corporate Culture And Performance. PT Prenhallindo. Simon And Sheester Pte,Ltd. Jakarta

Leslie W \& Philip G Hoil. (1996). Strategic Management, Concept And Experience, McGraw Hill Internasional. USA.

Ulul Albab, Vol. 5 No. 2, 2004 
Mangkunegara, A.P. (2001). Manajemen Sumber Daya Manusia Perusahaan. Edisi Baru. Remaja Resdakarya. Bandung.

McKenna, Eugene and Beech, Nick. (2000). The Essence Of Mangement: Manajemen Sumberdaya Manusia. Edisi Pertama. Cetakan Pertama. Terjemahan Totok Budi Santosa. Penerbit Andi dan Pearson Education Asia Pte.Ltd. Jakarta..

Nawawi, Ismail. (2000). Pelatihan Dan Kinerja. APSMI. Surabaya.

Nimran, Umar. (1999). Perilaku Organisasi. Edisi Revisi. Citra Media. Surabaya.

Nurfarhati. (1999). Pengaruh Budaya Organisasi Terhadap Kinerja. Tesis. Tidak dipublikasikan. Pascasarjana Universitas Brawijaya. Malang.

Rianto, B.S. (1999). Membangun Budaya Polri Yang Berorientasi Madani. Makalah Seminar. Jakarta.

Ricardo, Ronald And Jennifer, Jolly. (1997). Organization Culture And Teams. Sam Advance Mangement Journal. Spring.

Robbins, Stephen. (1996). Perilaku Organisasi: Konsep, Kontroversi Dan Aplikasi. Edisi Kedua. Terjemahan Pudjaatmaka. Prenhallindo. Jakarta.

Roesmanhadi. (1999). Membangun Kultur Baru Polri. Makalah Seminar. Yogyakarta.

Santoso, Singgih. (2000). SPSS Mengolah Data Statistik Secara Profesional. Cetakan Kedua. Elex media Computindo. Jakarta.

Semeru. (2003). Kredibilitas Polisi Dimata Masyarakat. Majalah: Temprina Media Grafika. Surabaya.

Simamora, H. (1997). Manajemen Sumber Daya Manusia. Cetakan Pertama, STIE YPKN. Yogyakarta..

Sudjana. (1992). Metode Statistika. Edisi kelima. Tarsito. Bandung.

Sugiarto. (1992). Tahap Awal Dan Aplikasi : Analisis Regresi, Andi Offset. Yogyakarta.

Sugiyono. (1999). Metode Penelitian Bisnis. Penerbit Alfabeta. Bandung..

Timpe, A Dale (1999). Kinerja (Sari Manajemen Sumber Daya Manusia). Cetakan keempat, Gramedia Pustaka Utama, Jakarta

Tjiptono, Fandy. (1996). Manajemen Jasa. Andi Offset. Yogyakarta.

Umar, H. (2001). Riset Sumber Daya Manusia Dalam Organisasi. Cetakan Keempat. Penerbit Gramedia Pustaka Utama. Jakarta. 
Undang-undang Republik Indonesia Nomor 2 Tahun 2002. Tentang Kepolisian Negara Republik Indonesia. Diskum Polda Jatim, Surabaya.

www.polri.co.id

Yukl, Gary. (1998). Leadership In Organization. Alih Bahasa: Udaya Yusuf. Kepemimpinan Dalam Organisasi. Prenhallindo. Jakarta. 